\title{
Circadian Rhythm and Larvicidal Activity Against Aedes aegypti of Essential Oils from Croton piauhiensis
}

\author{
Silva, P. T.; Silva, H. C.; Vale, J. P. C.; Frota, V. M.; Rodrigues, T. H. S.; \\ Souza, E. B.; Bandeira, P. N.; Teixeira, A. M. R.; Santiago, G. M. P.; \\ Santos, H. S.*
}

Rev. Virtual Quim., 2019, 11 (6), 1682-1692. Data de publicação na Web: 14 de outubro de 2019

http://rvq.sbq.org.br

\section{Ritmo Circadiano e Atividade Larvicida contra Aedes aegypti de Óleos Essenciais de Croton piauhiensis}

\begin{abstract}
Resumo: Croton piauhiensis Müll. Arg., popularmente conhecido como velame, é uma espécie restrita do bioma Caatinga. Neste contexto, este trabalho tem como objetivo estudar pela primeira vez o ciclo circadiano e a atividade larvicida contra - Aedes aegypti dos óleos essenciais de C. piauhiensis. A composição química dos óleos essenciais de folhas obtidas por hidrodestilação foi analisada e identificada por GC-MS e GC-FID. De acordo com os resultados, o estudo circadiano mostrou diferenças na composição química dos óleos extraídos em diferentes horas do dia das folhas de $C$. piauhiensis. Os principais componentes dos óleos essenciais das folhas de $C$. piauhiensis são obtidos às $8 \mathrm{~h}, 12 \mathrm{~h}$ e $17 \mathrm{~h}$, foram $\beta$-cariofileno 21,58, 34,69 e 21,01 \%, D-limoneno 13,47, 13,75 e 16,35, $\gamma$-terpineno 10,08, 8,00 e 9,60\%, germacreno D 9,56, 10,42 e $8,71 \%$, respectivamente. $O$ teor de sesquiterpenos foi de $52,59 \%$ e $67,29 \%$ às $8 \mathrm{~h}$ e $12 \mathrm{~h}$, respectivamente. Por outro lado, às $17 \mathrm{~h}$ houve maior predominância dos monoterpenos (50,77 \%). Em relação à atividade larvicida, os óleos essenciais de $C$. piauhiensis apresentaram atividade larvicida com $\mathrm{CL}_{50}=336,8 \mu \mathrm{g} / \mathrm{mL}$ (óleo extraído às 8:00 h), $\mathrm{CL}_{50}=283,9 \mu \mathrm{g} / \mathrm{mL}$ (óleo extraído a partir das 12:00 h) e $\mathrm{CL}_{50}=252,5 \mu \mathrm{g} / \mathrm{ml}$ (óleo extraído às 17:00 h).
\end{abstract}

Palavras-chave: Croton piauhiensis; óleos essenciais; ciclo circadiano.

\begin{abstract}
Croton piauhiensis, popularly known as velame, is a restricted species of Caatinga biome. In this context, this work aims to study for the first time the circadian cycle and larvicidal activity against Aedes aegypti of the essential oils from $C$. piauhiensis. The chemical composition of the essential oils from leaves obtained by hydrodistillation was analyzed and identified by GC-MS and GC-FID. According to the results, the circadian study showed differences in the chemical composition of oils extracted from C. piauhiensis leaves collected at different hours of the day. The major components of essential oils from $C$. piauhiensis collected at 8,12 and $17 \mathrm{~h}$, were $\beta$-caryophyllene $21.58,34.69$ and $21.01 \%$, D-limonene 13.47, 13.75 and $16.35, \gamma$-terpinene $10.08,8.00$ and $9.60 \%$, germacrene $D$ 9.56, 10.42 and $8.71 \%$, respectively. Sesquiterpenes contents were $52.59 \%$ and $67.29 \%$ at 8 and $12 \mathrm{~h}$, respectively. On the other hand, at in the oil collected $17 \mathrm{~h}$ there was a greater predominance of the monoterpenes (50.77\%). Regarding the larvicidal activity, the essential oils of $C$. piauhiensis showed larvicidal activity with $\mathrm{LC}_{50}=336.8 \mu \mathrm{g} / \mathrm{mL}$ (oil extracted at 8:00 h), $\mathrm{LC}_{50}=283.9 \mu \mathrm{g} / \mathrm{mL}$ (oil extracted at 12:00 h) and $\mathrm{LC}_{50}=252.5 \mu \mathrm{g} / \mathrm{ml}$ (oil extracted at 17:00 h).
\end{abstract}

Keywords: Croton piauhiensis; essential oils; circadian rhythm.

\footnotetext{
* Universidade Estadual Vale do Acaraú, Av. da Universidade 850. CEP 62040-370, Sobral-CE, Brasil.

Mhelciodossantos@gmail.com DOI: $\underline{10.21577 / 1984-6835.20190118}$
} 


\section{Circadian Rhythm and Larvicidal Activity Against Aedes aegypti of Essential Oils from Croton piauhiensis}

\section{Priscila T. da Silva, ${ }^{a}$ Horlando C. Silva, ${ }^{b}$ Jean P. C. do Vale, ${ }^{c}$ Vanessa M. Frota, ${ }^{\mathrm{c}}$ Tigressa H. S. Rodrigues, ${ }^{\mathrm{c}}$ Elnatan B. de Souza, ${ }^{\mathrm{d}}$ Gilvandete M. P. Santiago, ${ }^{b, e}$ Paulo N. Bandeira ${ }^{a, c}$ Alexandre M. R. Teixeira, ${ }^{a}$ Hélcio $S$. Santos ${ }^{\mathrm{a}, \mathrm{c}, *}$}

a Universidade Regional do Cariri, Programa de Pós-Graduação em Química Biológica, Departamento de Química Biológica, Campus Pimenta II, CEP 63100-000, Crato-CE, Brasil.

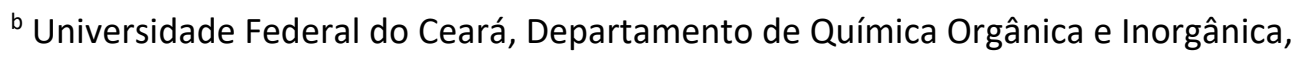
CEP 60451-970, Fortaleza-CE, Brasil.

' Universidade Estadual Vale do Acaraú, Centro de Ciências Exatas e Tecnologia, CEP 62040-370, Campus Betânia, Sobral-CE, Brasil.

d Universidade Estadual Vale do Acaraú, Curso de Ciências Biológicas, Centro de Ciências Agrárias e Biológicas, CEP 62040-370, Campus Betânia, Sobral-CE, Brasil.

e Universidade Federal do Ceará, Departamento de Farmácia, CEP 60430-160, Fortaleza-CE, Brasil.

* helciodossantos@gmail.com

Recebido em 12 de fevereiro de 2019. Aceito para publicação em 3 de setembro de 2019

\section{Introduction}

\section{Materials and Methods}

2.1. Plant material

2.2. Extraction of the essential oils

2.3. Gas Chromatography- Flame Ionization Detection (GC-FID)

2.4. Gas Chromatography-Mass Spectrometry (GC-MS)

2.5. Larvicidal bioassay

2.6. Statistical analysis

\section{Results and Discussion}

4. Conclusion

\section{Introduction}

Plants are sources of several bioactive secondary metabolites, and natural products from plants are very interesting and promising, mainly due to their potential 
applications in the food and pharmaceutical industries. ${ }^{1-3}$ Essential oils (EOs) are defined as a complex mixture of volatile substances, which can be extracted from different parts of the plant such as flowers, fruits, seeds, leaves, wood, bark and roots. ${ }^{4}$ In addition, several biological activities have been attributed to EOs including antiviral, ${ }^{5,6}$ insecticidal, ${ }^{7}$ antiparasitic, ${ }^{8,9}$ antimicrobial and antioxidant. ${ }^{10-12}$

Dengue, Zika and Chikumgunya are arboviruses with the highest circulation in Brazil, they are characterized by a group of viral diseases, transmitted by vectors, which can be transmitted to humans and other animals through the bite of Aedes aegypti. The World Health Organization (WHO) recognized these as a global public health problem and estimates that 50 to 100 million cases of infection occur worldwide each year. $^{13}$ The use of organophosphate insecticides for vector control can result in serious environmental problems like insecticide resistance and environmental pollution. ${ }^{14}$ In view of the serious epidemiological picture reported and considering the absence of a specific treatment, it is essential to identify EOs that have repellent, larvicidal and insecticidal properties in the control of these arboviruses. ${ }^{15}$

Croton (Euphorbiaceae) is the second largest genus in its family, with approximately
1.300 species distributed throughout tropical and subtropical regions. Some species of the genus Croton have been used in folk medicine for the treatment and cure of some diseases. ${ }^{16}$ Furthermore, several studies have reported the chemical characterization and biological activities of EOs extracted from Croton species. ${ }^{17-21}$

In recent years, the search for efficient natural compounds with larvicidal activity against $A$. aegypti and low environmental toxicity has increased, thus EOs of Croton species are outstanding candidates, since they are in some cases, they are readily available, and economically viable. In fact, the larvicidal activity of EOs extracted from $C$. zehntneri, $\quad C$. jacobinensis, $C$. argyrophylloides, C. sonderianus, $C$. nepetaefolius and $C$ regelianus have been previously reported. ${ }^{22-25}$

Croton piauhiensis (Figure 1) is an endemic species in Northeastern Brazil, found frequently in the Caatinga biome and popularly known as "velame" and "marmeleiro". There are no reports on the chemical composition and biological activities of $C$. piauhiensis essential oil. In this context, the present work aimed to evaluate for the first time the influence of the circadian cycle and larvicidal activity against $A$. aegypti of the essential oils from leaves of $C$. piauhiensis. 


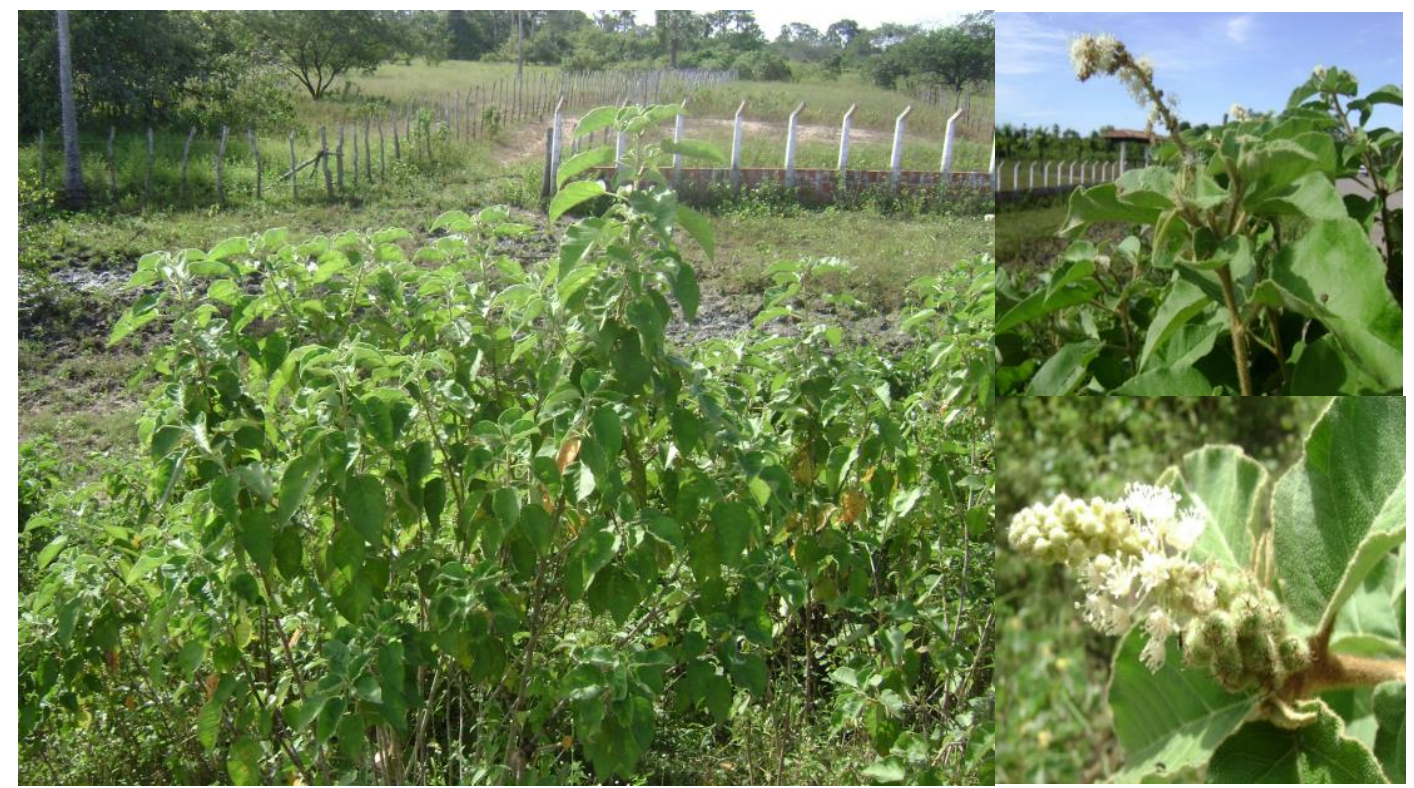

Figure 1. C. piauhiensis

\section{Materials and Methods}

\subsection{Plant material}

C. piauhiensis leaves were collected in Sobral, Ceará, Brazil $\left(03^{\circ} 36^{\prime} 44^{\prime \prime} \mathrm{S} 40^{\circ} 18^{\prime} 37^{\prime \prime}\right.$ W). Plant authentication was performed by Professor Daniela Santos Carneiro-Torres, and a voucher specimen was deposited at the Universidade Estadual de Feira de Santana (HUEFS) with the identification number \#14989.

\subsection{Extraction of the essential oils}

The fresh leaves of $C$. piauhiensis were subjected to hydrodistillation in a Clevengertype apparatus for 2 hours. After being filtered and dried over anhydrous sodium sulfate, the isolated oils were stored in sealed glass vials, which were maintained under refrigeration at $4{ }^{\circ} \mathrm{C}$ until GC- MS and GC-FID analysis.

\subsection{Gas Chromatography- Flame Ionization Detection}

GC-FID for the quantitative analysis was carried out on a Shimadzu GC-17A gas chromatograph using a dimethylpolysiloxane DB-5 fused silica capillary column $(30 \mathrm{~mm} x$ $0.25 \mathrm{~mm}$, film thickness $0.25 \mathrm{~m}$ ). $\mathrm{H}_{2}$ was used as the carrier gas at a flow rate of $1 \mathrm{~mL} / \mathrm{min}$ and 30 psi inlet pressure; split, 1:30; temperature program: $35-180{ }^{\circ} \mathrm{C}$ at $4{ }^{\circ} \mathrm{C} / \mathrm{min}$, then heated at a rate of $17{ }^{\circ} \mathrm{C} / \mathrm{min}$ to $280{ }^{\circ} \mathrm{C}$ and held isothermal for $10 \mathrm{~min}$; injector temperature, $250{ }^{\circ} \mathrm{C}$; detector used FID, detector temperature, $250{ }^{\circ} \mathrm{C}$.

\subsection{Gas Chromatography-Mass Spectrometry}

GC-MS for the analysis of the volatile constituents was carried out on a HewlettPackard Model 5971 GC/MS using a nonpolar DB-5 fused silica capillary column (30 $\mathrm{mm} \times 0.25 \mathrm{~mm}$ i.d., $0.25 \mathrm{~m}$ film thickness); carrier gas helium, flow rate $1 \mathrm{~mL} / \mathrm{min}$ and with split ratio $1: 1$. The injector temperature and detector temperature were $250{ }^{\circ} \mathrm{C}$ and $200{ }^{\circ} \mathrm{C}$, respectively. The column temperature 
was programmed from $35 \mathrm{C}$ to $180{ }^{\circ} \mathrm{C}$ at $4{ }^{\circ} \mathrm{C} / \mathrm{min}$ and then $180 \mathrm{C}$ to $250{ }^{\circ} \mathrm{C}$ at $10{ }^{\circ} \mathrm{C} / \mathrm{min}$. Mass spectra were recorded from $30-450 \mathrm{~m} / \mathrm{z}$. Individual components were identified by matching their $70 \mathrm{eV}$ mass spectra with those of the spectrometer data base using the Wiley L-built library MS searches using retention indices as a preselection routine, as well as by visual comparison of the fragmentation pattern with those reported in the literature. ${ }^{26}$

\subsection{Larvicidal bioassay}

Essential oils were placed in beakers and dissolved in $20 \mathrm{~mL} \mathrm{H} \mathrm{H}_{2} \mathrm{O} / \mathrm{DMSO} 1.5 \%(\mathrm{v} / \mathrm{v})$ at concentrations of $50-500 \mu \mathrm{g} / \mathrm{mL}$, followed by the addition of 50 larvae at the third-instar. For each experiment, both positive (Temephos ${ }^{\circledast}$ at $3.22 \mu \mathrm{g} / \mathrm{mL}$ ) and negative (distilled water containing $1.5 \%$ DMSO) control assays were carried out. Mortality was recorded after $24 \mathrm{~h}$ of exposure, during which no nutritional supplement was added. The experiments were carried out at $28 \pm$ $2{ }^{\circ} \mathrm{C}$. Each test was performed in triplicate. Data were evaluated through regression analysis. From the regression line, the $\mathrm{LC}_{50}$ values were read representing the lethal concentration for $50 \%$ larval mortality of $A$. aegypti. The bioassays were performed at the Laboratório de Entomologia, Núcleo de Endemias, Secretaria de Saúde do Estado do Ceará, Brazil. ${ }^{27}$

\subsection{Statistical analysis}

The $L C_{50}$ value of essential oil from leaves of $C$. piauhiensis was calculated using the probit analysis of the mortality data derived from bioassays. ${ }^{28}$

\section{Results and Discussion}

The EOs extracted from the leaves of $C$. piauhiensis at 8,12 and $17 \mathrm{~h}$ were analyzed by GC/MS and GC/FID (Table 1 ). A total of 28 constituents $(97.68 \%)$ were identified in the extracted essential oil at $8 \mathrm{~h}$, being 13 monoterpenes (44.86 \%) and 15 sesquiterpenes ( $55.59 \%)$. For the essential oil extracted at 12 h, 21 constituents (97.65\%) were identified, being 10 monoterpenes (32.47\%) and 11 sesquiterpenes (67.29\%), whereas in the essential oil extracted at $17 \mathrm{~h}$, 22 constituents $(98.74 \%)$ were identified, being 10 monoterpenes (50.77\%) and 12 sesquiterpenes (47.96\%).

The EOs obtained at $12 \mathrm{~h}$ showed a greater abundance of sesquiterpenes. In its identified composition, $46.43 \%$ corresponds to thirteen monoterpenes, three oxygenates and ten non-oxygenated, $53.57 \%$ correspond to fifteen sesquiterpenes, nine nonoxygenated and six oxygenated. The major components of essential oils from $C$. piauhiensis at 8,12 and $17 \mathrm{~h}$ were $\beta$ caryophyllene $21.58,34.69$ and $21.01 \%$, Dlimonene 13.47, 13.75 and $16.35, \gamma$-terpinene $10.08,8.00$ and $9.60 \%$, Germacrene D 9.56, 10.42 and $8.71 \%$, respectively (Figure 2 ).

It is observed that the harvesting time influenced expressively the terpenic composition of the EOs, since there are variations in the percentage of monoterpenes and sesquiterpenes throughout the three evaluated schedules. At $8 \mathrm{~h}$, the percentage of monoterpenes and sesquiterpenes were $44.89 \%$ and $52.59 \%$, respectively. This result was different from that obtained in the $12 \mathrm{~h}$, for the percentages of monoterpenes (32.47 \%) and sesquiterpenes (67.29\%). At that time, the predominance of sesquiterpene compounds, which are less volatile than monoterpenes, can be attributed to the high ambient temperatures that are reached at this time (12h), when compared to the other collection schedules studied. At the time of $17 \mathrm{~h}$, the percentage of monoterpenes $(50.77 \%$ ) was higher than that of sesquiterpenes (47.96\%).

The chemical composition of EOS from $C$. piauhiensis showed a greater abundance of monoterpenes and sesquiterpenes. Similar 
results were achieved by different studies with the same genus, showing also the predominance of monoterpenes and sesquiterpenes..$^{29,30}$ Moreover, the major constituents of the essential from $C$. piauhiensis were $\beta$-caryophyllene, $D$ limonene, germacrene $D$ and $\gamma$-terpinene. In fact, these components appear in other studies as main constituents of essential oils from different Croton species. Moreover, in the essential oils from some Croton species, such as $C$. rhamnifolioides, $C$. conduplicatus, C. decaryi and $C$. geayi, $\beta$-caryophyllene is the most abundant constituent. ${ }^{31,32}$

The circadian variation in EOs from leaves of $C$. piauhiensis was affected by climatic conditions, resulting in the production of different constituents in different proportions. The factors, such as temperature, solar radiation intensity, rainfall index, etc., act with varying degrees of intensity, mediating the quantity and nature of the substances produced..$^{33}$ The influence of edaphoclimatic factors can be observed in EOs of Ocimum gratissimum, whose eugenol content is about $11 \%$ at 12 and $98 \%$ at 5 h. ${ }^{34}$

Larvicidal activity of EOs of the some species from genus Croton has been previously reported, for instance, EOs from leaves, stalks and inflorescences of $C$. zehntneri and $C$. jacobinensis showed $\mathrm{LC}_{50}$ values of $56.2,51.3,57.5$ and $79.3,117.2$, $65.8 \mu \mathrm{g} / \mathrm{mL}$, respectively, were tested at different concentrations against $A$. aegypti. ${ }^{22,23}$ EOs from aerial parts of $C$ argyrophylloides, $C$. sonderianus and $C$. nepetaefolius showed $\mathrm{LC}_{50}$ values of 94.6 , 54.5 and $66.4 \mu \mathrm{g} / \mathrm{mL}$, respectively, ${ }^{24}$ and whereas EOs from leaves of $C$. regelianus growing in two different sites at Ceará State (Brazil) showed $\mathrm{LC}_{50}$ values of 24.22 and $66.74 \mu \mathrm{g} / \mathrm{mL}^{25}$

The larvicidal activity from leaves EOs of $C$. piauhiensis were evaluated against $A$. aegypti using Temephos ${ }^{\circ} \quad\left(0, O^{\prime}\right.$-(thiodi-4,1phenylene) bis (O,O-dimethyl phosphorothioate) as positive control. The mortality percentages were calculated after $24 \mathrm{~h}$. The larvicidal effects of these essential oils are shown in Table 2 . The essential oils obtained at 8,12 and $17 \mathrm{~h}$ showed $\mathrm{LC}_{50}$ values of of $336.8,283.9$ and $252.5 \mu \mathrm{g} / \mathrm{mL}$, respectively. Therefore, the different activities of the essential oils can be attributed to the variation of their chemical compositions.

Essential oils from the leaves of $C$. piauhiensis demonstrated larvicidal activity against Aedes aegypti, which can be explained by a possible relationship between larvicidal activity and the presence of monoterpenes ( $\alpha$-pinene, sabinene, $\beta$ pinene, myrcene, $\alpha$-terpinene, $D$-limonene and $\quad \gamma$-terpinene, terpinen-4-ol) and sesquiterpenes (b-caryophyllene and germacrene $D$ ) which have been reported to be active against $A$. aegypti and can serve to increase the transmembrane absorption of lipophilic drugs, which can kill larvae of $A$. aegypti and mediate synergistic effects. ${ }^{35-38}$ 
Silva, P. T. et al.

Table 1. Chemical composition of essential oil from leaves of $C$. piauhiensis

\begin{tabular}{|c|c|c|c|c|c|}
\hline \multirow{2}{*}{ Compounds } & \multirow[t]{2}{*}{$\mathbf{R I}^{\mathbf{a}}$} & \multirow[t]{2}{*}{$\mathbf{R} \mathbf{I}^{\mathbf{b}}$} & \multicolumn{3}{|c|}{$\%$} \\
\hline & & & $8.00 \mathrm{~h}$ & $12.00 \mathrm{~h}$ & $17.00 \mathrm{~h}$ \\
\hline$\alpha$-Thujene & 933 & 924 & 0.62 & 0.45 & 0.59 \\
\hline$\alpha$-Pinene & 941 & 932 & 1.22 & 1.10 & 2.37 \\
\hline Sabinene & 979 & 969 & 3.41 & 1.52 & 3.61 \\
\hline$\beta$-Pinene & 984 & 974 & 0.24 & 1.48 & 0.30 \\
\hline Myrcene & 994 & 988 & 3.34 & 0.45 & 3.89 \\
\hline$\alpha$-Terpinene & 1023 & 1017 & 0.57 & & 0.53 \\
\hline$p$-Cymene & 1031 & 1024 & 1.31 & 0.91 & 1.37 \\
\hline D-Limonene & 1034 & 1029 & 13.47 & 13.75 & 16.35 \\
\hline Eucalyptol & 1037 & 1031 & 4.92 & 3.14 & 6.88 \\
\hline$\gamma$-Terpinene & 1064 & 1059 & 10.08 & 8.00 & 9.60 \\
\hline Terpinolene & 1093 & 1088 & 1.35 & 1.67 & 1.32 \\
\hline Linalool & 1104 & 1096 & 2.33 & & 2.41 \\
\hline Terpinen-4-ol & 1183 & 1177 & 2.03 & & 1.55 \\
\hline$\delta$-Elemene & 1341 & 1338 & 0.62 & & 0.71 \\
\hline$\alpha$-Copaene & 1379 & 1376 & 0.64 & 0.65 & 0.59 \\
\hline$\beta$-Elemene & 1394 & 1390 & 1.63 & 1.40 & 1.96 \\
\hline$\beta$-Caryophyllene & 1423 & 1419 & 21.58 & 34.69 & 21.01 \\
\hline$\alpha$-Caryophyllene & 1457 & 1454 & 2.54 & 4.30 & 2.46 \\
\hline Germacrene D & 1484 & 1485 & 9.56 & 10.42 & 8.71 \\
\hline Bicyclogermacrene & 1498 & 1500 & 6.62 & 8.49 & 6.94 \\
\hline$\nu$-Cadinene & 1517 & 1513 & 0.55 & & \\
\hline$\delta$-Cadinene & 1526 & 1523 & 1.45 & 1.50 & 1.17 \\
\hline Spathulenol & 1581 & 1578 & 0.90 & & \\
\hline Caryophyllene oxide & 1586 & 1583 & 1.29 & 1.84 & 0.83 \\
\hline 1-epi-Cubenol & 1632 & 1628 & 0.37 & & \\
\hline a-epi-Muurolol & 1646 & 1642 & 3.03 & 1.84 & 1.39 \\
\hline$\delta$-Cadinol & 1650 & 1646 & 0.79 & 1.15 & 1.56 \\
\hline$\alpha$-Cadinol & 1659 & 1654 & 1.02 & 1.01 & 0.63 \\
\hline & & & 97.48 & 97.65 & 98.74 \\
\hline
\end{tabular}

${ }^{a}$ Retention index on DB-5 column; ${ }^{b}$ Literature retention index 


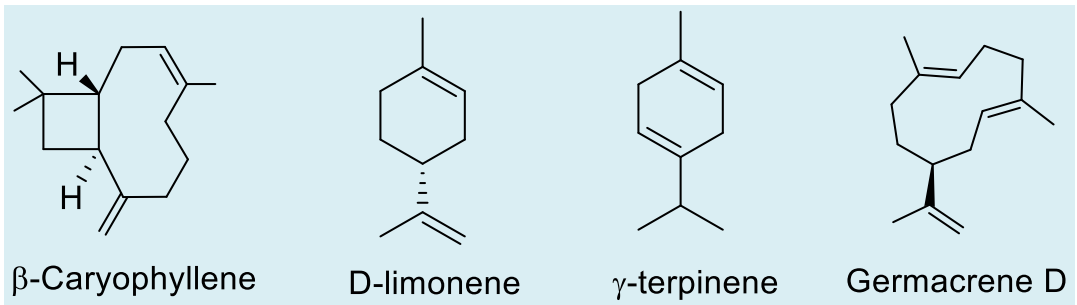

Figure 2. The main constituents of the essential oil from the leaves of $C$. piauhiensis

Table 2. Larval mortality (\%) and $\mathrm{LC}_{50}$ values of essential oils against third-instar of Aedes aegypti larvae

\begin{tabular}{cccc}
\hline Essential oil & $\begin{array}{c}\text { Concentration } \\
(\mu \mathrm{g} / \mathrm{mL})\end{array}$ & $\begin{array}{c}\text { Average }(\%) \text { of dead larvae } \\
\text { after } \mathbf{2 4} \mathbf{h}(\%)\end{array}$ & $\begin{array}{c}\mathbf{L C}_{50} \\
(\mu \mathrm{g} / \mathrm{mL})\end{array}$ \\
\hline \multirow{3}{*}{$8.00 \mathrm{~h}$} & 500 & 98.7 & 336.8 \\
& 250 & 4.0 & \\
& 100 & 0.0 & \\
& 50 & 0.0 & 283.9 \\
& 500 & 90.8 & \\
& 250 & 38.0 & \\
& 100 & 8.7 & 252.5 \\
& 50 & 0.0 & \\
& 500 & 99.46 & \\
& 250 & 48.7 & \\
& 100 & 28.00 & \\
& 50 & 8.7 & \\
\hline
\end{tabular}

\section{Conclusion}

The circadian study of essential oils from C. piauhiensis allowed us to conclude that the variations observed in the concentration of the chemical constituents can be attributed to environmental conditions. The major components of essential oils from $C$. piauhiensis were $\beta$-caryophyllene, $D$ limonene, $\quad \gamma$-terpinene and germacrene D. Additionally, essential oils from the leaves of C. piauhiensis demonstrated larvicidal activity against Aedes aegypti, which can be explained by a possible relationship between larvicidal activity and the presence of monoterpenes and sesquiterpenes since these substances can serve to increase the transmembrane absorption of lipophilic drugs, which can kill larvae of $A$. aegypti and mediate synergistic effects.

\section{Acknowledgments}

The authors are grateful to the Fundação Cearense de Apoio ao Desenvolvimento Científico e Tecnológico (FUNCAP), Conselho Nacional de Desenvolvimento Científico e Tecnológico (CNPq). EMBRAPA AGROINDÚSTRIA TROPICAL-Laboratório Multiusuário de Química de Produtos Naturais by obtaining the spectral data. H. S. 
Santos, T. H. S. Rodrigues and E. B. Souza, acknowledges financial support from the $P Q$ BPI/FUNCAP (grant \#: 00026.01.00/15), (grant \#: 4017807/18 and grant \#: 013900252.01.00/18).A. M. R. Teixeira, Ph. D. also acknowledges financial support from the CNPq (grant \#: 305719/2018-1).

\section{References}

${ }^{1}$ Christaki, E.; Bonos, E.; Giannenas, I.; Florou-Paneri, P. Aromatic plants as a source of bioactive compounds, Agriculture 2012, 2, 228. [CrossRef]

${ }^{2}$ Brusotti, G.; Cesari, I.; Dentamaro, A.; Caccialanza, G.; Massolini, G. Isolation and characterization of bioactive compounds from plant resources: The role of analysis in the ethnopharmacological approach. Journal of Pharmaceutical and Biomedical Analysis 2014, 87, 218. [CrossRef]

${ }^{3}$ Atanasov, A. G.; Waltenberger, B.; PferschyWenzig, E. M.; Linder, T.; Wawrosch, C.; Uhrin, P.; Temml, V.; Wang, L.; Schwaiger, S.; Heiss, E. H.; Rollinger, J. M.; Schuster, D.; Breuss, J. M.; Bochkov, V.; Mihovilovic, M. D.; Kopp, B.; Bauer, R.; Dirsch, V. M.; Stuppner, $H$. Discovery and resupply of pharmacologically active plant-derived natural products: A review. Biotechnology Advances 2015, 33, 1582. [CrossRef]

${ }^{4}$ Sarto, M. P. M.; Zanusso Junior, G. Atividade Antimicrobiana de óleos essenciais. Revista Uninguá Review 2014, 20, 98. [Link]

${ }^{5}$ Gavanji, S.; Sayedipour, S. S.; Larki, B.; Bakhtari, A. Antiviral activity of some plant oils against herpes simplex virus type 1 in Vero cell culture. Journal of Acute Medicine 2015, 5, 62. [CrossRef]

${ }^{6}$ Gomes, M. R. F.; Schuh, R. S.; Jacques, A. L. B.; Dorneles, G. G.; Montanha, J.; Roehe, P. M.; Bordignon, S.; Dallegrave, E.; Leal, M. B.; Limberger, R. P. Biological assessment (antiviral and antioxidant) and acute toxicity of essential oils from Drimys angustifolia and D. brasiliensis. Revista Brasileira de Farmacognosia 2013, 23, 284. [CrossRef]
7 Jalaei, Z.; Fattahi, M.; Aramideh, S. Allelopathic and insecticidal activities of essential oil of Dracocephalum kotschyi Boiss. from Iran: A new chemotype with highest limonene-10-al and limonene. Industrial Crops and Products 2015, 73, 109. [CrossRef]

${ }^{8}$ Gaínza, Y. A.; Domingues, L. F.; Perez, O. P.; Rabelo, M. D.; López, E. R.; Chagas, A. C. S. Anthelmintic activity in vitro of Citrus sinensis and Melaleuca quinquenervia essential oil from Cuba on Haemonchus contortus. Industrial Crops and Products 2015, 76, 647. [CrossRef]

${ }^{9}$ Pillai, S.; Mahmud, R.; Lee, W. C.; Perumal, S. Anti-parasitic activity of Myristica fragrans Houtt. essential oil against Toxoplasma gondii parasite. APCBEE Procedia 2012, 2, 92. [CrossRef]

${ }^{10}$ Martucci, J. F.; Gende, L. B.; Neira, L. M.; Ruseckaite, R. A. Oregano and lavender essential oils as antioxidant and antimicrobial additives of biogenic gelatin films. Industrial Crops and Products 2015, 71, 205. [CrossRef]

11 Zantar, S.; Haouzi, R.; Chabbi, M.; Laglaoui, A.; Mouhib, M.; Mohammed, B.; Bakkali, M.; Zerrouk, M. H. Effect of gamma irradiation on chemical composition, antimicrobial and antioxidant activities of Thymus vulgaris and Mentha pulegium essential oils. Radiation Physics and Chemistry 2015, 115, 6. [CrossRef]

12 Muriel-Galet, V.; Cran, M. J.; Bigger, S. W.; Hernández-Muñoz, P.; Gavara, R. Antioxidant and antimicrobial properties of ethylene vinyl alcohol copolymer films based on the release of oregano essential oil and green tea extract components. Journal of Food Engineering 2015, 149, 9. [CrossRef]

${ }^{13}$ Chanyasanha, C.; Guruge, G. R.; Sujirarat, D. Factors influencing preventive behaviors for dengue infection among housewives in Colombo, Sri Lanka. Asia-Pacific Journal of Public Health 2015, 27, 96. [CrossRef]

${ }^{14}$ Silva, I. M. A.; Martins, G. F.; Melo, C. R.; Santana, A. S.; Faro, R. R. N.; Blank, A. F.; Alves, P. B.; Picanço, M. C.; Crislaldo, P. F.; Araújo, A. P. A.; Bacci, L. Alternative control of Aedes aegypti resistant to pyrethroids: 
lethal and sublethal effects of monoterpene bioinsecticides. Pest Management Science 2018, 74, 1001. [CrossRef] [PubMed]

${ }^{15}$ Vasantha-Srinivasan, P.; Senthil-Nathan, S.; Ponsankar, A.; Thanigaivel, A.; Edwin, E.-S.; Selin-Rani, S.; Chellappandian, M.; Pradeepa, V.; Lija-Escaline, J.; Kalaivani, K.; Hunter, W. B.; Duraipandiyan, V.; Al-Dhabi, N. A.. Comparative analysis of mosquito (Diptera: Culicidae: Aedes aegypti Liston) responses to the insecticide Temephos and plant derived essential oil derived from Piper betle L. Ecotoxicology and Environmental Safety 2017, 139, 439. [CrossRef] [PubMed]

16 Salatino, A., Salatino, M. L. F.; Negri, G. Traditional uses, chemistry and pharmacology of Croton species (Euphorbiaceae). Journal of the Brazilian Chemical Society 2007, 18, 11. [CrossRef]

${ }^{17}$ Morais, S. M.; Catunda Júnior, F. E. A.; Silva, A. R. A.; Martins Neto, J. S.; Rondina, D.; Cardoso, J. H. L. Atividade antioxidante de óleos essenciais de espécies de Croton do Nordeste do Brasil. Química Nova 2006, 29, 907. [CrossRef]

${ }^{18}$ Alviano, W. S.; Mendonca-Filho, R. R.; Alviano, D. S.; Bizzo, H. R.; Souto-Padron, T.; Rodrigues, M. L.; Bolognese, A. M.; Alviano, C. S.; Souza, M. M. G. Antimicrobial activity of Croton cajucara Benth linalool-rich essential oil on artificial biofilms and planktonic microorganisms. Oral Microbiology and Immunology 2005, 20, 101. [CrossRef]

${ }^{19}$ Costa, J. G. M.; Rodrigues, F. F. G.; Angélico, E. C.; Pereira, C. K. B.; Souza, E. O.; Caldas, G. F. R.; Silva, M. R.; Santos, N. K. A.; Mota, M. L.; Santos, P. F. Composição química e avaliação da atividade antibacteriana e toxicidade do óleo essencial de Croton zehntneri (variedade estragol), Revista Brasileira de Farmacognosia 2008, 18, 583. [CrossRef]

${ }^{20}$ Costa, A. C. V.; Melo, G. F. A.; Madruga, M. S.; Costa, J. G. M.; Junior, F. G.; Neto, V. Q. Chemical composition and antibacterial activity of essential oil of Croton rhamnifolioides leaves Pax \& Hoffm. Semina:
Ciências Agrárias 2013, 34, 2853. [CrossRef]

${ }^{21}$ Silva-Almeida, J. R. G.; Souza, A. V. V.; Oliveira, A. P.; Santos, U. S.; Souza, M. D.; Bispo, L. P.; Turatti, I. C. C.; Lopes, N. P. Chemical composition of essential oils from the stem barks of Croton conduplicatus (Euphorbiaceae) native to the Caatinga biome. African Journal of Pharmacy and Pharmacology 2015, 9, 98. [Link]

${ }^{22}$ Santos, H. S.; Santiago, G. M. P.; Oliveira, J. P. P.; Arriaga, A. M. C.; Marques, D. D.; Lemos, T. L. G. Chemical composition and larvicidal activity against Aedes aegypti of essential from Croton zehntneri. Natural Product Communications 2007, 2, 1233. [Link]

${ }^{23}$ Pinto, C. C. C.; Menezes, J. E. S. A.; Siqueira, S. M. C.; Melo, D. S.; Feitosa, C. R. S.; Santos, H. S. Chemical Composition and larvicidal activity against Aedes aegypti of essential oils from Croton jacobinenesis Baill. Boletín Latinoamericano y Del Caribede Plantas Medicinales y Aromáticas 2016, 15, 122. [Link]

${ }^{24}$ de Lima, G. P. G.; de Souza, T. M.; Freire, G. P.; Farias, D. F.; Cunha, A. P.; Ricardo, N. M. P. S.; de Morais, S. M.; Carvalho, A. F. U. Further insecticidal activities of essential oils from Lippia sidoides and Croton species against Aedes aegypti L. Parasitology Research 2013, 112, 1953. [CrossRef]

${ }^{25}$ Torres, M. C. M.; Assuncão, J. C.; Santiago, G. M. P.; Andrade-Neto, M.; Silveira, E. R.; Costa-Lotufo, L. V.; Bezerra, D. P.; Marinho Filho, J. D. B.; Viana, F. A.; Pessoa, O. D. L. Larvicidal and nematicidal activities of the leaf essential oil of Croton regelianus. Chemistry \& Biodiversity 2008, 5, 2724. [CrossRef]

${ }^{26}$ Adams R. P.; Identification of Essential Oil Components by Gas Chromatography/Quadrupole Massa Spectroscopy. Allured Publ Corp Carol Stream: Illinois, 2017.

${ }^{27}$ Souza, L. G. S.; Almeida, M. C. S.; Monte, F. J. Q.; Santiago, G. M. P.; Braz-Filho, R.; Lemos, T. L. G.; Gomes, C. L.; Nascimento, R. F. Constituintes químicos de Capraria biflora (Scrophulariaceae) e atividade larvicida de 
seu óleo essencial. Química Nova 2012, 35, 2258. [CrossRef]

${ }^{28}$ Silva, P. T.; Santos, H. S.; Teixeira, A. M. R.; Bandeira, P. N.; Holanda, C. L.; Vale, J. P. C.; Pereira, E. J. P; Menezes, J. E. S. A.; Rodrigues, T. H. S.; Souza, E. B.; Silva, H. C.; Santiago, G. M. P. Seasonal variation in the chemical composition and larvicidal activity against Aedes aegypti of essential oils from Vitex gardneriana Schauer. South African Journal of Botany 2019, 124, 329. [CrossRef]

${ }^{29}$ Meccia, G.; Rojas, L. B.; Rosquete, C.; Feleciano, A. S. Essential oil of Croton ovalifolius Vahl from Venezuela. Flavour Fragrance Journal 2000, 15, 144. [CrossRef]

${ }^{30}$ Fontenelle, R. O. S.; Morais, S. M.; Brito, E. H. S.; Brilhante, R. S. N.; Cordeiro, R. A.; Nascimento, N. R. F.; Kerntopf, M. R.; Sidrim, J. J. C.; Rocha, M. F. G. Antifungal activity of essential oils of Croton species from the brazilian Caatinga biome. Journal of Applied Microbiology 2008, 104, 1383. [CrossRef] [PubMed]

${ }^{31}$ Radulovic, N.; Mananjaraso, E.; Harinantenaina, L.; Yoshinori, A. Essential oil composition of four Croton species from Madagascar and their chemotaxonomy. Biochemical Systematics and Ecology 2006, 34, 648. [CrossRef]

32 Morais, S. M.; Cavalcanti, E. S. B.; Bertini, L. M.; Oliveira, C. L. L.; Rodrigues, J. R. B.; Cardoso, J. H. L. Larvicidal activity of essential oils from Brazilian Croton species against Aedes aegypti L. Journal of the American Mosquito Control Association 2006, 22, 161. [CrossRef] [PubMed]
${ }^{33}$ Cerqueira, M. D.; Marques, E. J.; Martins, D.; Roque, N. F.; Cruz, F. G.; Guedes, M. L. S. Variação sazonal da composição do óleo essencial de Myrcia salzmannii Berg. (Myrtaceae). Química Nova 2009, 32, 1544. [CrossRef]

${ }^{34}$ Silva, M. G. V.; Craveiro, A. A.; Matos, F. J. A.; Machado, M. L.; Alencar, J. W. Chemical variation during daytime of constituents of the essential oil of Ocimum gratissimum leaves. Fitoterapia 1999, 70, 32. [CrossRef]

${ }^{35}$ Pavela, R. Essential oils for the development of eco-friendly mosquito larvicides: A review. Industrial Crops and Products 2015, 76, 174. [CrossRef]

${ }^{36}$ Dias, C. N.; Moraes, D. F. C. Essential oils and their compounds as Aedes aegypti L. (Diptera: Culicidae) larvicides: review. Parasitology Research 2014, 113, 565. [PubMed]

${ }^{37}$ Pereira, E. J. P.; Silva, H. C.; Holanda, C. L.; Menezes, J. E. S. A.; Siqueira, S. M. C.; Rodrigues, T. H. S.; Fontenelle, R. O. S.; Vale, J. P. C.; Silva, P. T.; Santiago, G. M. P.; Santos, H. S. Chemical composition, cytotoxicity and larvicidal activity against Aedes aegypti of essential oils from Vitex gardineriana Schauer. Boletín Latinoamericano y del Caribe de Plantas Medicinales y Aromáticas 2018, 17, 302. [Link]

${ }^{38}$ El-Kattan, A. F.; Asbill, C. S.; Kim, N.; Michniak, B. B. The effects of terpene enhancers on the percutaneous permeation of drugs with different lipophilicities. International Journal of Pharmaceutics 2001, 215, 229. [CrossRef] [PubMed] 